\title{
SPATIAL DIVERSITY OF ENTREPRENEURSHIP IN COMMUNES OF THE ŚWIĘTOKRZYSKIE VOIVODSHIP IN 2009-2017
}

\author{
Paweł Dziekański ${ }^{1}$, Adrian Lipa ${ }^{2}$, Anna Novoseletska ${ }^{3}$
}

\begin{abstract}
The region includes a part of the economic space separated from the environment that is developed by a given community and interrelated economic entities. Owned territorial capital means that regions differ in the scale of entrepreneurship. The purpose of the article is to analyze and evaluate the spatial diversity of entrepreneurship in municipalities using a synthetic measure. The analysis was made in the system of 102 rural communes of the Świętokrzyskie Voivodship. The source material was data from the Local Database of the Central Statistical Office for 2009-2017. In analyzing the diversity of entrepreneurship in communes of the Świętokrzyskie Voivodship, synthetic measure based on the TOPSIS method was used. In 2017, TOPSIS's synthetic measure of entrepreneurship ranged from 0.39 (Waśniów (2)) to 0.81 (Kielce (1)). The best group includes units with an industrial function and a developing labor market, a developed tourist or spa function. The group of Kielce (1), Sandomierz (1), SkarżyskoKamienna (1) and Ostrowiec Świętokrzyski (1), as the leading units in the analyzed period, is also indicated by gravity analysis (indicating the concentration of the phenomenon in the central region of the region). As a result of the analysis, it has been established that the condition for creating growth is the creation of permanent spatial systems resulting from the activities of enterprises. In the short term, enterprises generate local economic growth.
\end{abstract}

Key words: synthetic measure, entrepreneurship, municipalities, Świętokrzyskie Voivodship.

JEL Classification: C38, H76, L26, M19, 012

\section{Introduction}

The region is a social and economic system comprising a separate part of the economic space developed by a given community and functioning of the various interrelated economic entities (Huczek, 2016). The development possibilities of the regions are determined by their endogenous (territorial) capital and exogenous environment. A. Klasik and F. Kuźnik define regional development as a long-term increase in the economic potential of regions, their competitive strength and the quality of life of residents. The essence of regional development is to ensure cohesion in its three dimensions: economic, social and territorial (Klasik, Kuźnik, 2001).

The structural features of regions and their territorial capital strengthen regional diversity and the scale of entrepreneurial activity. Factors creating or blocking entrepreneurship in the region include: demographic region, regional labor market, quality of human capital,

\footnotetext{
Corresponding author:

${ }^{1}$ Jan Kochanowski University in Kielce, Poland.

ORCID: https://orcid.org/0000-0003-4065-0043

E-mail: pdziekan@interia.eu

ResearcherID: H-4658-2016

${ }^{2}$ Scientific and Educational Consortium in Kielce, Poland.

ORCID: https://orcid.org/0000-0001-7949-3044

E-mail: adrianlipa@konsorcjum.edu.pl

${ }^{3}$ National University of Ostroh Academy, Ukraine.

ORCID: https://orcid.org/0000-0003-2992-5237

E-mail: anna.novoseletska@oa.edu.ua
}

entrepreneurship of the region, housing resources, infrastructure equipment. Entrepreneurship is an interdisciplinary, multifaceted and complex concept. It is important for social and economic development. Entrepreneurship is considered in terms of process, set of features, innovation and as a factor influences regional development (Miłek, Kantarek, 2017).

Entrepreneurship, as E. Skawińska indicates, plays an important role in the efficient allocation of existing resources of the region. It concerns the actions of people in the process of seeking innovation and detecting new relationships in the economic and social system (Skawińska, 2009). A. Klasik indicates that entrepreneurship is the basis of the attractiveness of the regional economies and their communities. It is a socially conditioned process of creating opportunities for creating wealth, using financial and material resources as well as human capital in an innovative way (Klasik, 2006). 


\section{Material and research method}

The purpose of the article is to analyze and evaluate the spatial diversity of entrepreneurship in municipalities using a synthetic measure. The analysis was made in the system of 102 rural communes of the Świętokrzyskie Voivodship. The material used was the data from the Local Data Bank of the Central Statistical Office for 2009-2017.

In analyzing the diversity of entrepreneurship in communes of the Świętokrzyskie Voivodship, a synthetic measure based on the TOPSIS method was used. The following stages were used in the conducted research:

I. The stimulant and destimulant sets were determined and presented in the form of an observation matrix $x_{i j}$ :

$$
x_{i j}=\left[\begin{array}{cccc}
x_{11} & x_{12} & \ldots & x_{1 m} \\
x_{21} & x_{22} & \ldots & x_{2 m} \\
\ldots & \ldots & \ldots & \ldots \\
x_{n 1} & x_{n 2} & \ldots & x_{n m}
\end{array}\right]
$$

where $x_{i j}$ - denotes the values of the $j$-th feature for the $i$-th object $(i=1,2, \ldots, n ; j=1,2, \ldots, m)$.

From the set of variables, those with low spatial variability (coefficient of variation less than 0.10 ) and high correlation of variables (according to the inverse correlation matrix) were removed (Malina, 2004). The set of variables selected for analysis is presented in Table 1.

Table 1

List of variables describing entrepreneurship potential in communes

\begin{tabular}{|l|c|}
\hline \multicolumn{1}{|c|}{ Variables } & S/D \\
\hline Entities entered into REGON register & $\mathrm{S}$ \\
\hline Newly registered units in the REGON register & $\mathrm{S}$ \\
\hline Units removed from the REGON register & $\mathrm{D}$ \\
\hline Self-employed persons & $\mathrm{S}$ \\
\hline Net migration rate & $\mathrm{S}$ \\
\hline Registered unemployed persons & $\mathrm{D}$ \\
\hline Employed in communes & $\mathrm{S}$ \\
\hline
\end{tabular}

as - stimulant; $\mathrm{d}$ - destimulant

Source: study based on data available at the Central Statistical Office of Poland (CSO)

II. Selected destimulants were replaced with a stimulant according to the formula;

$$
x_{i j}=\frac{1}{x_{i j}}
$$

III. Stimulants were subjected to the unitarization procedure zeroed according to the formula:

$$
\text { for stimulants } z_{i j}=\frac{\mathrm{x}_{i j}-\min _{i} \mathrm{x}_{i j}}{\max _{i} \mathrm{x}_{i j}-\min _{i} x_{i j}} \text { when } x_{i} \in S
$$

where: $S$ - stimulant, $D$ - destimulant; $i=1,2 \ldots n$; $j=1,2 \ldots n, x_{i j}-$ means the value of the $j$-th feature for the examined unit, max - the maximum value of the $j$-th feature, min - the minimum value of the $j$-th feature (Wysocki, Lira, 2005; Kukuła, 2000; Młodak, 2006). As a result of the unitarisation process, the matrix of property values was obtained $z_{i j}$ :

$$
z_{i j}=\left[\begin{array}{cccc}
z_{11} & z_{12} & \ldots & z_{1 m} \\
z_{21} & z_{22} & \ldots & z_{2 m} \\
\ldots & \ldots & \ldots & \ldots \\
z_{n 1} & z_{n 2} & \ldots & z_{n m}
\end{array}\right]
$$

where $z_{i j}$ is the unified value of $x_{i j}$.

IV. The measure of entrepreneurship was determined based on the TOPSIS method. As part of the method, Euclidean distances of communes from the pattern $(=1)$ and antipattern $(=0)$ were determined, according to the following formulas:

$$
\begin{aligned}
& d_{i}^{+}=\sqrt{\frac{1}{n} \sum_{j=1}^{m}\left(z_{i j}-z_{j}^{+}\right)^{2}} \\
& d_{i}^{-}=\sqrt{\frac{1}{n} \sum_{j=1}^{m}\left(z_{i j}-z_{j}^{-}\right)^{2}}
\end{aligned}
$$

where $\mathrm{n}$ - stands for the number of variables making up the synthetic measure, $z_{i j}$ - stands for the unified value of the $\mathrm{j}$-th feature for the tested unit, $z_{j}^{+}, z_{j}^{-}-$stands for the pattern or antipattern object (Wójcik-Leń, Leń, Mika, Kryszk, Kotlarz, 2019; Behzadian, Khanmohammadi Otaghsara, Yazdani, Ignatius, 2012; Zalewski, 2012).

The synthetic measure (TOPSIS) was determined for municipalities based on the formula:

$$
q_{i}=\frac{d_{i}^{-}}{d_{i}^{-}+d_{i}^{+}}, \text {where } 0 \leq q_{i} \leq 1, i=1,2, \ldots, n ;
$$

with: $q_{i} \in[0 ; 1] ; d_{i}^{-}$means the distance of the object from the antipattern (from 0 ), $d_{i}^{+}$means the distance of the object from the pattern(from 1). A higher value of measure indicates a better situation of the individual in the studied area ${ }^{1}$.

V. Finally, the study area was divided into 4 quartile groups. The first, second and third quartiles were used as threshold values. The size of the synthetic measure in the first group means a better unit, the weakest in the last one. The mutual compliance of the results obtained was also verified based on the correlation coefficient. A scatter chart with an adjustment line for synthetic measures is also presented (Zeliaś, Malina, 1997).

\section{Entrepreneurship and regional development}

Municipalities do not develop evenly. This is due to uneven access to factors of production. The endogenous

${ }^{1}$ C.L. Hwang, K. Yoon, 1981, Multiple attribute decision making. Methods and applications, Springer, Berlin, For: A. Bieniasz, Z. Gołaś, A. Euczak, 2013, Zróżnicowanie kondycji finansowej gospodarstw rolnych wyspecjalizowanych $w$ chowie owiec $i$ kóz $w$ krajach Unii Europejskiej, Roczniki Ekonomii Rolnictwa i Rozwoju Obszarów Wiejskich, T. 100, z. 1; M.B. Pietrzak, 2016, The problem of the inclusion of spatial dependence within the TOPSIS Method. Montenegrin Journal of Economics, vol. 12(3), p. 69-86. 
potential of the individual, the potential inherent in people and local entrepreneurship is also important. It should be remembered that development is not only the effect of the activities of the administration but also of the simultaneous operation of enterprises. According to J. Paryska, local development is a long-term process of social and economic development, using local development factors (Parysek, 2001). R. Brol defines local development as the activity of the local community, local authority and business entities operating in the commune. Their activities are aimed at creating new and improving the existing utility and competitive values of the commune and creating favorable conditions for the local economy (Brol, 1998).

The development of communes can be considered on its three main planes: social, ecological and economic. A characteristic feature of development is the relatively low mobility of major development factors. These include, among others: the state of infrastructure, qualifications of the workforce, social structure, branch structure of the local economy. There are dependencies between external and internal factors of development. These relationships are an important driving force for development. Internal and external factors (entrepreneurship, economic, social, spatial, political and ecological, unique to the local system) can interact with different strength and character (Korenik, 1999).

R. Brol indicates that entrepreneurship should be treated as an endogenous factor in the development of the regional economy (Brol, 2006). In addition to the economic function, it carries out a social, economic and ecological function. T. Markowski indicates that entrepreneurship is an attribute of social capital (Markowski, 2008). W. Kosiedowski emphasizes the economic dimension of entrepreneurship in shaping regional development (Kosiedowski, 2008). In order for entrepreneurship to have a real impact on the development of the region, favorable economic, mental, legal and institutional conditions must exist (KolaBezka, 2010) in it.

Factors affecting the level of entrepreneurship include: demographics of the region, labor market, economic structures of the region, human capital, housing resources, infrastructure equipment. The development of entrepreneurship should be considered in the broader context of the elements constituting local development. These elements are: environment, culture, community, economy and power.

Entrepreneurship plays an important role in the process of economic development of the region. It provides an opportunity to increase development potential. It enables the effective use of endogenous resources of the region and obtaining exogenous ones. Creating the right conditions for the development of local entrepreneurship is one of the main tasks of local government. In this respect, municipalities have, among others, short- and long-term financial instruments and technical infrastructure, with the help of which they can influence local economic life.

There are many entrepreneurship development barriers and their rank is different. Some of them have the nature of macroeconomic restrictions related to solutions resulting from the socio-economic policy of the state, the economic system and formal and legal solutions (Zarębski, 2002). Others regarding the amount of taxes, as well as fees provided for by law, lack of suitably qualified employees, waiting time for payment from a contractor, barriers to innovation and access to information.

\section{Diversification of entrepreneurship in rural communes of the Świętokrzyskie Voivodship}

The Świętokrzyskie Voivodship is located in the southeastern part of Poland. The area of the Świętokrzyskie Voivodship is $11691.05 \mathrm{~km}^{2}, 66 \%$ of the area of the Voivodship is the protected area. Świętokrzyskie has an industrial and agricultural character ${ }^{2}$. The main industries of the Świętokrzyskie Voivodship are: metallurgical (Ostrowiec Świętokrzyski), metal (Skarżysko-Kamienna), machine (Starachowice), construction materials (Kielce), ceramic, foundry (Końskie), food (Pińczów, Kielce). The economy of the Świętokrzyskie region is based on the mining industry in the field of construction materials (limestone, dolomites, marls, gypsum, sandstone), due to which the voivodship has gained the name of the capital of the Polish construction. The agricultural south is the base for the production of organic food (Jóźwiak, Jóźwiak, Strzyż, 2010).

In 2017, the synthetic measure of TOPSIS entrepreneurship ranged from 0.39 (Waśniów (2); Ostrowiecki County) to 0.81 (Kielce (1), regional capital). The best group $\mathrm{A}$ includes units with an industrial function (Kielce (1), Sandomierz (1), Skarżysko-Kamienna (1), Ostrowiec Świętokrzyski cities of the region) and a developing (developed) labor market, developed tourist or spa function (e.g. Busko-Zdrój (3). In the weakest group D and units with an agricultural function (e.g. Działoszyce (3), Klimontów (2), Koprzywnica (3), Michałów (2), Ruda Maleniecka (2), Waśniów (2), Iwaniska (2), Nowy Korczyn $(2)^{3}$, the process of human capital leaching and the weak market work (see Figure 1).

The dispersion analysis (Figure 2) of the measure of synthetic entrepreneurship in communes of the Świętokrzyskie Voivodship in 2009 and 2017 indicates a slight increase in diversity. Outliers were Kielce

\footnotetext{
${ }^{2}$ Charakterystyka dotyczy przewagi danego rodzaju działalności w regionie: przemysłowa północ i rolnicze południe.

${ }^{3}$ (1) gminy miejskie, (2) gminy wiejskie, (3) gminy miejsko-wiejskie
} 


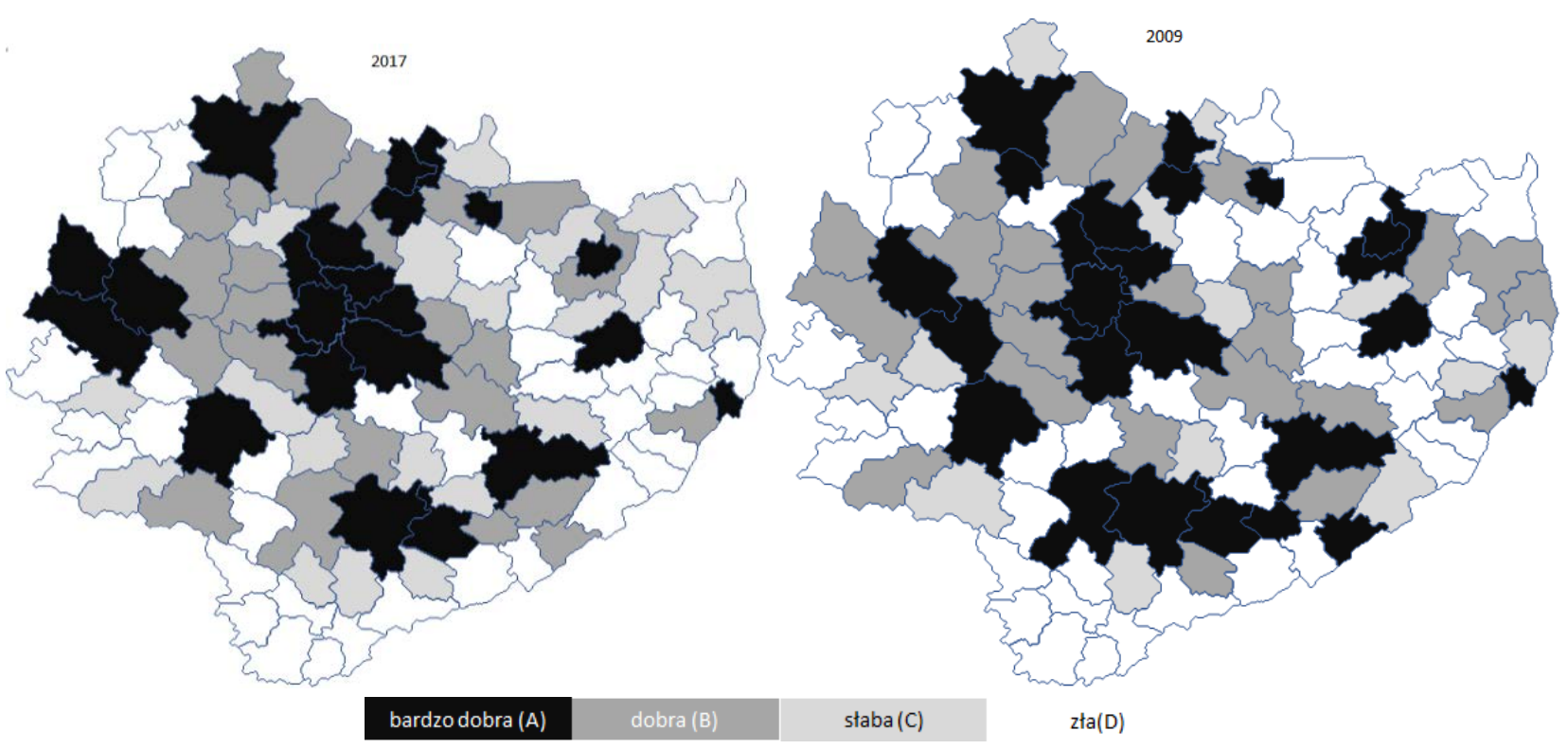

Figure 1. Spatial differentiation of the synthetic measure TOPSIS entrepreneurship of communes of the Świętokrzyskie Voivodship in 2009 and 2017

Source: the author's own development based on BDL GUS

(1), Sandomierz (1), Skarżysko-Kamienna (1), Masłów (2), Busko-Zdrój (3), Ostrowiec Świętokrzyski (1), Miedziana Góra (2), Końskie (3). These are units located in the central part of the region with a developed industrial function and a developing labor market.

Measures of spatial differentiation indicate the relative stability of communes in the aspect of entrepreneurship measure (Table 2). In 2017, compared to 2009, the results show stability according to the standard deviation (0.06-0.06), the classic coefficient of variation (0.13-0.13), the quarterly range (0.05-0.05). The range of 0.33-0.41 indicates an increase in diversity (small changes in the area under study).

Pearson's correlation coefficient between the value of the synthetic entrepreneurship measure in 2017 in relation to 0.953 in 2009 (Figure 3). It can be assumed that the spatial diversity of the studied area was quite stable, and the units reacted similarly to changes in the economy. Outstanding units are: Kielce (1), Sandomierz

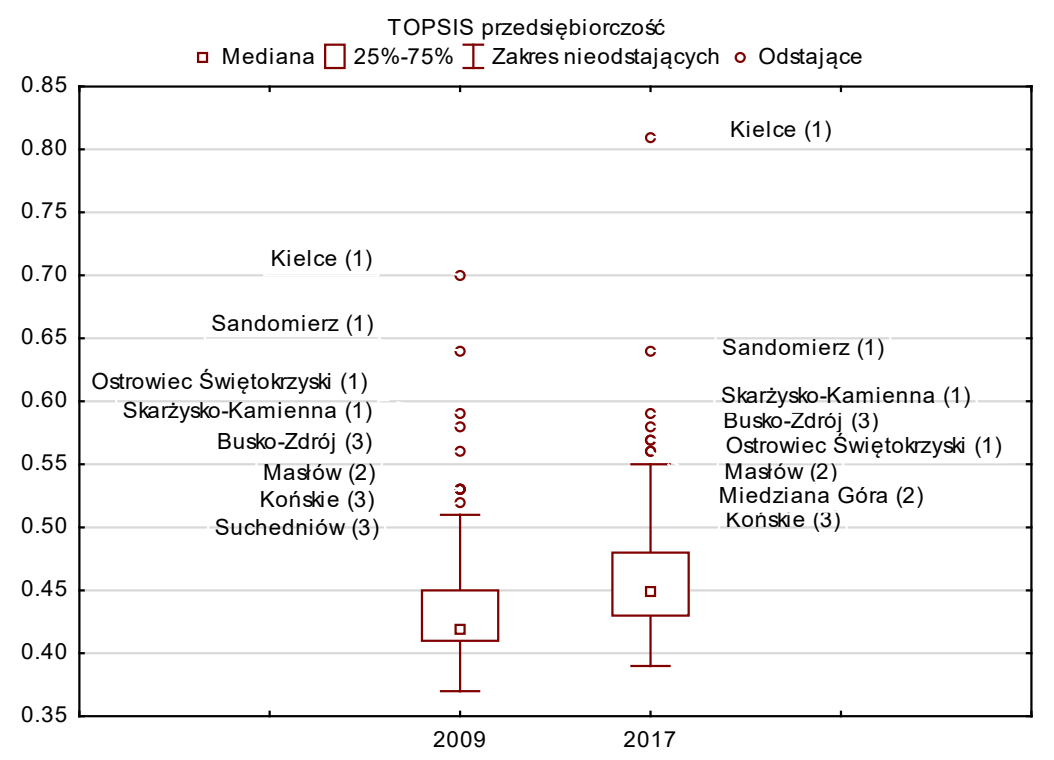

Figure 2. Dissipation of the synthetic measure of entrepreneurship TOPSIS of communes of the Świętokrzyskie voivodship in 2009 and 2017

Source: the author's own development based on BDL GUS 
Vol. 6, No. 4, 2020

Table 2

Dissipation of the synthetic measure of entrepreneurship TOPSIS

of communes of the Świętokrzyskie voivodship in 2009 and 2017

\begin{tabular}{|l|l|l|}
\hline & 2009 & 2017 \\
\hline average & 0.44 & 0.47 \\
\hline median & 0.42 & 0.45 \\
\hline standard deviation & 0.06 & 0.06 \\
\hline quarter (quartile) deviation & 0.43 & 0.45 \\
\hline classic coefficient of variation & 0.13 & 0.13 \\
\hline positional coefficient of variation & 1.01 & 1.01 \\
\hline min. & 0.37 & 0.39 \\
\hline max & 0,70 & 0.81 \\
\hline range & 0.33 & 0.41 \\
\hline quartile 1 & 0.41 & 0.43 \\
\hline quartile 2 & 0.42 & 0.45 \\
\hline quartile 3 & 0.45 & 0.48 \\
\hline quartile range & 0.05 & 0.05 \\
\hline skewness & 2.04 & 2.51 \\
\hline measure concentration - kurtosis & 5.23 & 10.36 \\
\hline
\end{tabular}

Source: the author's own development based on BDL GUS

(1), Ostrowiec Świętokrzyski (1). These are cities that have a developed industrial function.

The gravitational effect, indicating the effect of concentration of the phenomenon, connecting two communes is directly proportional to the product of the competitive potential of these communes and inversely proportional to the square of the geographical distance separating these units. Municipalities with high development potential located close to each other have a stronger impact than those located far apart (Filipowicz, Tokarski, 2015).
The first group (Figure 4) for the TOPSIS measure consists of central municipalities (26; units with an industrial, tourist, spa, developing labor market; among others, Kielce (1), Masłów (2), Daleszyce (3), Morawica (2), Miedziana Góra (2), SitkówkaNowiny (2), Zagnańsk (2), Bieliny (2), BuskoZdrój (3), Suchedniów (3), Skarżysko-Kamienna (1), Starachowice (1), Chęciny (3), Bodzentyn (3), Staszów (3)). The second and third groups are 25 and 27 units. The weakest group is 24 units with a peripheral character (units with an agricultural function, a process

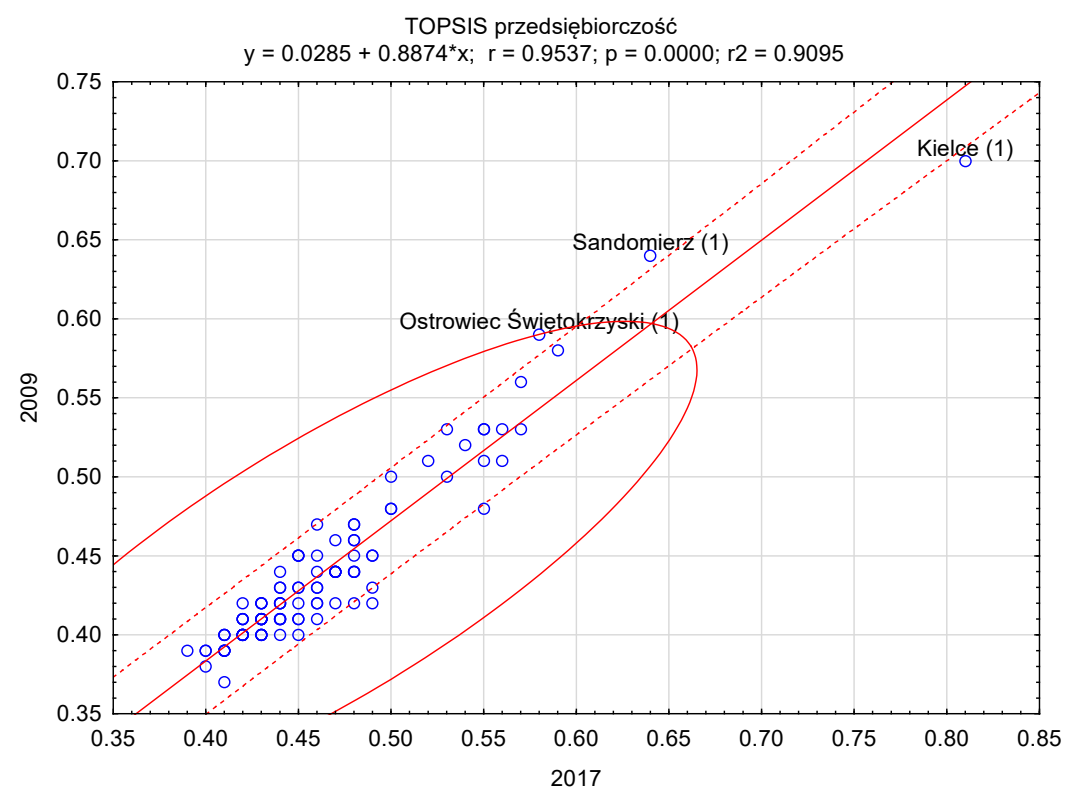

Figure 3. Year-to-year ratio of synthetic measures - entrepreneurship TOPSIS of communes of the Świętokrzyskie Voivodship in 2009 and 2017

Source: the authors' own development based on BDL GUS 


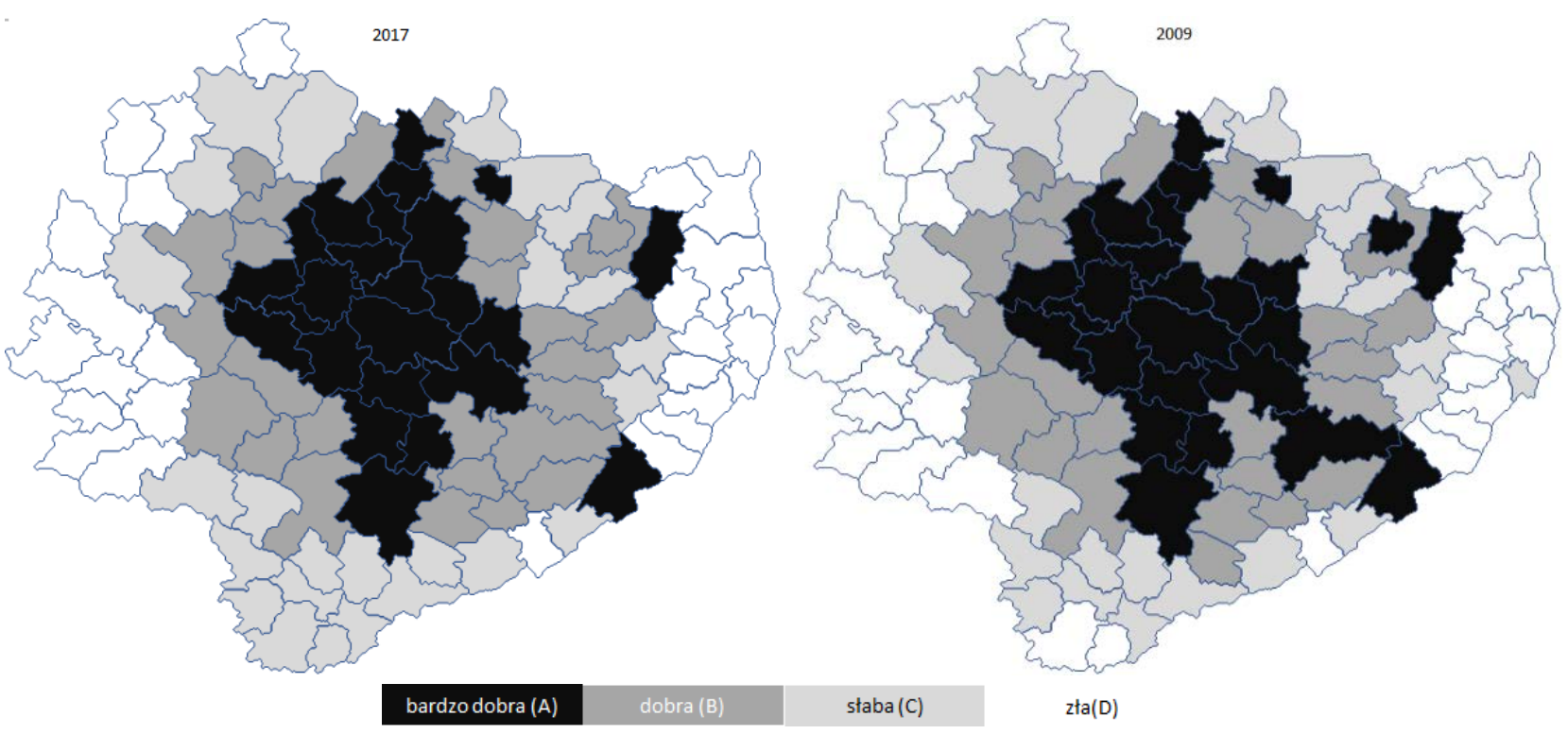

Figure 4. Result of the gravity analysis (concentration) for the synthetic measure TOPSIS entrepreneurship of communes of the Świętokrzyskie Voivodship in 2009 and 2017

Source: the author's own development based on BDL GUS

of human capital leaching and a weak labor market; among others, Łoniów (2), Samborzec (2), Ożarów (3), Wojciechowice (2), Koprzywnica (3), Włoszczowa (3), Bałtów (2), Dwikozy (2), Tarłów (2), Zawichost (3)).

The level of entrepreneurship in communes of the Świętokrzyskie Voivodship was influenced by: the number of the unemployed and employed, entities conducting economic activity, micro-entities (employing from 0 to 9), macro-entities (10-49) and medium (50-249), newly registered and entities removed from the register economic entities and natural persons conducting economic activity.

To assess the impact of selected elements of endogenous potentials of communes on the spatial diversity of the measure of synthetic entrepreneurship, a regression model describing the dependence of variables has been estimated taking the form:

$$
\begin{aligned}
& \mathrm{F} \text { (TOPSIS entrepreneurship) }= \\
& =\sum \text { (TOPSIS development, Registered unemployed } \\
& \text { persons, Employed in communes, Own income, } \\
& \text { Investment expenditures, Population } \\
& \text { in the working-age, Migration balance). }
\end{aligned}
$$

The regression analysis of the entrepreneurship measure versus selected endogenous potentials of communes in the Świętokrzyskie Voivodship explains $\mathrm{R}=0.781$ variable variations (at $\mathrm{R} 2=0.780$; the interpretation value of this model turns out to be satisfactory $\left.{ }^{4}\right)$. The statistics values $F(7,910)$ 466.31 and the corresponding probability level $\mathrm{p}$ mean that all parameters are statistically significant. Further increasing the multidimensionality of the model would cause a slight increase in R2. The model could include statistically insignificant variables.

\section{Conclusion}

The condition of the enterprises determines the economic situation of the region. The situation of enterprises operating in a given region should be of interest to both residents and entities making legal, economic and social decisions regarding the region. An attempt to apply a synthetic enterprise measure seems justified.

Economic potential is one of the most important factors for the development of municipalities. The high level of economic development creates positive conditions enabling the increase in the standard of living of the inhabitants or the development of enterprises.

An analysis of the dispersion of the measure of synthetic entrepreneurship in communes of the Swiętokrzyskie Voivodship indicates a slight increase in diversity. The level of entrepreneurship in communes of the Swiętokrzyskie Voivodship was influenced by: the number of the unemployed and employed, entities conducting economic activity, micro entities (employing from 0 to 9), macro entities (10-49) and medium (50-249), newly registered and entities removed from the register economic entities and natural persons conducting economic activity.

In 2017, the synthetic measure of TOPSIS entrepreneurship ranged from 0.39 (Waśniów (2); Ostrowiecki County) to 0.81 (Kielce (1), regional capital). The best group $\mathrm{A}$ includes units with an

\footnotetext{
${ }^{4}$ Skorygowany współczynnik determinacji nie osiągnął $60 \%$. Za optymalną wartość uważa się przekroczenie progu determinacji na poziomie $95 \%$.
} 
Table 3

Estimation of synthetic entrepreneurship and selected endogenous potentials of communes in the Świętokrzyskie province

\begin{tabular}{|c|c|c|c|c|}
\hline & Rate & Standard error & t-Student's & $\mathrm{p}$-value \\
\hline const & 0.152815 & 0.0328855 & 4.647 & $<0.0001$ \\
\hline TOPSIS development & 1.02534 & 0.0354469 & 28.93 & $<0.0001$ \\
\hline Registered unemployed & $3.86181 \mathrm{e}-06$ & $2.10744 \mathrm{e}-06$ & 1.832 & 0.0672 \\
\hline Working in communes & $2.08307 \mathrm{e}-06$ & $3.25707 \mathrm{e}-07$ & 6.396 & $<0.0001$ \\
\hline Own income & $-4.50888 \mathrm{e}-06$ & $2.32033 \mathrm{e}-06$ & -1.943 & 0.0523 \\
\hline Investment expenses & $-1.55529 \mathrm{e}-05$ & $1.85079 \mathrm{e}-06$ & -8.403 & $<0.0001$ \\
\hline Working age population & -0.00235618 & 0.000613920 & -3.838 & 0.0001 \\
\hline Net migration rate & 0.00100655 & 0.000273999 & 3,674 & 0.0003 \\
\hline
\end{tabular}

\begin{tabular}{|l|c|l|c|}
\hline Arithmetic mean of the dependent variable & 0.451427 & $\begin{array}{l}\text { Standard deviation of the dependent } \\
\text { variable }\end{array}$ & 0.055337 \\
\hline Sum of residual squares & 0.612168 & Residual Standard Error & 0.025937 \\
\hline Determining coefficient R- square & 0.781994 & Corrected R-square & 0.780317 \\
\hline F $(7,910)$ & 466.3134 & P-value for the F-test & $7.3 \mathrm{e}-296$ \\
\hline Logarithm of credibility & 2054.057 & Akaike's information criterion & -4.092 .113 \\
\hline Bayesian, Schwarz information criterion & -4053.536 & Hannan-Quinn criterion & -4077.390 \\
\hline
\end{tabular}

observations used 1-918; dependent variable TOPSIS entrepreneurship

Source: the authors' own development based on BDL GUS

industrial function and a developed labor market, a developed tourist or spa function. The group of Kielce (1), Sandomierz (1), Skarżysko-Kamienna (1), Ostrowiec Świętokrzyski (1), as the leading units in the analyzed period is indicated by gravity analysis (indicating the concentration of the phenomenon in the central region of the region).
The results of the study give local governments the opportunity to compare their own situation with the situation of neighboring municipalities or municipalities with similar economic and social conditions. The conclusions drawn on this basis may allow local authorities to set out potential directions for optimizing their economic policy.

\section{References:}

Behzadian, M., Khanmohammadi Otaghsara, S., Yazdani, M., \& Ignatius, J. (2012). A state-of the-art survey of TOPSIS applications, Expert Systems with Applications, 39(17).

Brol, R. (1998). Rozwój lokalny - nowa logika rozwoju gospodarczego, In: Gospodarka lokalna w teorii $i$ w praktyce, ed. M. Obrębalski, Akademia Ékonomiczna we Wrocławiu, Wrocław.

Brol, R. (2006). Czynniki rozwoju regionalnego, In: D. Strahl (ed.), Metody oceny rozwoju regionalnego, Wyd. AE we Wrocławiu, Wrocław.

Dziekański, P. (2016). Spatial Differentiation of the Financial Condition of the Świętokrzyskie Voivodship Counties, Barometr Regionalny, Tom 14, nr 3.

Filipowicz, K., \& Tokarski, T. (2015). Wpływ efektu grawitacyjnego na przestrzenne zróżnicowanie rozwoju ekonomicznego powiatów, Wiadomości Statystyczne, nr 5.

Filipowicz, K., \& Tokarski, T. (2015). Wpływ efektu grawitacyjnego na przestrzenne zróżnicowanie rozwoju ekonomicznego powiatów Polski Wschodniej, Studia i Materiały Miscellanea Oeconomicae, nr 4, tom I.

Huczek, M. (2016). Przedsiębiorczość i konkurencyjność w rozwoju regionalnym, ZN WSH Zarządzanie 2016 (3).

Hwang, C. L., \& Yoon, K. (1981). Multiple attribute decision making. Methods and applications, Springer, Berlin, For: A. Bieniasz, Z. Gołaś, A. Łuczak, 2013, Zróżnicowanie kondycji finansowej gospodarstw rolnych wyspecjalizowanych w chowie owiec i kóz w krajach Unii Europejskiej, Roczniki Ekonomii Rolnictwa i Rozwoju Obszarów Wiejskich, T. 100, z. 1.

Jóźwiak, M. A., Jóźwiak, M., \& Strzyż, M. (2010). Predyspozycje naturalne regionu świętokrzyskiego do rozwoju turystyki, Krajobraz a Turystyka, Prace Komisji Krajobrazu Kulturowego Nr 14, Komisja Krajobrazu Kulturowego PTG, Sosnowiec.

Klasik, A., \& Kuźnik, F. (2001). Konkurencyjny rozwój regionów w Europie, In: Konkurencyjność miast i regionów, ed. Z. Szymla, Akademia Ekonomiczna w Krakowie, Kraków.

Klasik, A. (2006). Przedsiębiorczość i konkurencyjność a rozwój regionalny, Wyd. AE w Katowicach, Katowice.

Kola-Bezka, M. (2010). Przyczynek do rozważań o przedsiębiorczości polskich regionów, Wyd. UMK, Toruń.

Korenik, S. (1999). Rozwój regionu ekonomicznego na przykładzie Dolnego Śląska, Wyd. AE we Wrocławiu, Wrocław. 
Kosiedowski, W. (2008). Zarządzanie rozwojem regionalnym i lokalnym, In: Z. Strzelecki (ed.), Gospodarka regionalna i lokalna, Wyd. Naukowe PWN, Warszawa.

Kukuła, K. (2000). Metoda unitaryzacji zerowanej, PWN, Warszawa.

Malina, A. (2004). Wielowymiarowa analiza przestrzennego zróżnicowania struktury gospodarki Polski wedtug województw, Wyd. Akademii Ekonomicznej w Krakowie, Kraków.

Markowski, T. (2008). Teoretyczne podstawy rozwoju lokalnego i regionalnego, In: Z. Strzelecki (ed.), Gospodarka regionalna i lokalna, Wyd. Naukowe PWN, Warszawa.

Miłek, D., \& Kantarek, I. (2017). Przedsiębiorczość w rozwoju polskich regionów, Nierówności Społeczne a Wzrost Gospodarczy, nr 50(2), doi: 10.15584/nsawg.2017.2.20.

Młodak, A. (2006). Analiza taksonomiczna w statystyce regionalnej, Centrum Doradztwa i Informacji Difin, Warszawa.

Nowak, E. (1990). Metody taksonomiczne w klasyfikacji obiektów spoteczno-gospodarczych, PWE, Warszawa.

Parysek, J. J. (2001). Podstawy gospodarki lokalnej, Uniwersytet im. Adama Mickiewicza w Poznaniu, Poznań.

Pietrzak, M. B. (2016). The problem of the inclusion of spatial dependence within the TOPSIS Method. Montenegrin Journal of Economics, 12(3).

Skawińska, E. (2009). Kapitat społeczny w rozwoju regionu, In: W. Janasz, Innowacje w strategii rozwoju organizacji $w$ Unii Europejskiej, Warszawa.

Tokarski, T. (2005). Statystyczna analiza regionalnego zróżnicowania wydajności, zatrudnienia i bezrobocia w Polsce, Wydawnictwo PTE, Warszawa.

Wójcik-Leń, J., Leń, P., Mika, M., Kryszk, H., \& Kotlarz, P. (2019). Studies regarding correct selection of statistical methods for the needs of increasing the efficiency of identification of land for consolidation - A case study in Poland. Land Use Policy.

Wysocki, F., \& Lira, J. (2005). Statystyka opisowa, Wyd. AR, Poznań.

Zalewski, W. (2012). Zastosowanie metody TOPSIS do oceny kondycji finansowej spótek dystrybucyjnych energii elektrycznej, Ekonomia i Zarządzanie, 4.

Zarębski, M. (2002). Czynniki rozwoju matych i średnich przedsiębiorstw na obszarach wiejskich, In: Przedsiębiorstwo $i$ jego otoczenie w warunkach integracji europejskiej, Uniwersytet Warmińsko-Mazurski, Olsztyn.

Zeliaś, A., \& Malina, A., (1997). O budowie taksonomicznej miary jakości życia. Syntetyczna miara rozwoju jest narzędziem statystycznej analizy porównawczej, Taksonomia z. 4. 